\title{
Influence of flow rate, fluid temperature, and extension line on Hotline and S-line heating capability: an in vitro study
}

\author{
Hosu Kim ${ }^{1 \dagger}$, Tae Kyong Kim ${ }^{1,2 \dagger}$, Sukha Yoo ${ }^{3}$ and Jin-Tae Kim ${ }^{1,3^{*}}$ [D
}

\begin{abstract}
Background: A fluid warmer can prevent hypothermia during the perioperative period. This study evaluated the heating capabilities of Hotline and Barkey S-line under different flow rates and initial fluid temperatures, as well as after the extension line installation.

Methods: We measured the temperature of a $0.9 \%$ sodium chloride solution at the fluid warmer outlet (TProx) and the extension line end (TDistal) with three different initial fluid temperatures (room, warm, and cold) and two flow rates $(250 \mathrm{ml} / \mathrm{hr}$ and $100 \mathrm{~mL} / \mathrm{hr}$ ).

Results: At a $250 \mathrm{ml} / \mathrm{hr}$ flow rate, the TProx and TDistal values were observed to be higher in Hotline than in S-line when using room-temperature or cold fluid. Administering of the warm fluid at the same flow rate significantly increased the TProx and TDistal values in S-line more than the cold and room-temperature fluids. At flow rates of $100 \mathrm{ml} / \mathrm{hr}$, TDistal values were significantly lower than TProx values in both devices regardless of the initial fluid temperature.

Conclusions: Hotline outperformed S-line for warming fluids at a high flow rate with cold or room-temperature fluids. Administering warm fluid in S-line prevented a decrease in the fluid temperature at a high flow rate. However, at a low flow rate, the fluid temperature significantly decreased in both devices after passing through an extension line.
\end{abstract}

Keywords: Hypothermia, Barkey S-line, Flow rate, Extension line, Fluid temperature, Heating capability

\section{Background}

Inadvertent perioperative hypothermia commonly occurs in patients undergoing surgery on account of a cold operating room, anesthetic agents that weaken thermoregulatory control, and administration of un-warmed fluid [18]. Even mild hypothermia, defined as a core body temperature ranging from 34 to $36{ }^{\circ} \mathrm{C}$, is associated with complications, such as an increased need for a blood transfusion, increased length of hospitalization, a higher

\footnotetext{
*Correspondence: jintae73@gmail.com

Hosu Kim and Tae Kyong Kim contributed equally as the first authors of this manuscript.

'College of Medicine, Seoul National University, Seoul, Republic of Korea

${ }^{3}$ Department of Anesthesiology and Pain Medicine, Seoul National University Hospital, 101 Daehak-ro, Jongno-gu, 03080 Seoul, Republic of Korea

Full list of author information is available at the end of the article
}

incidence of postoperative myocardial infarction, and the risk of developing a surgical wound infection [7-10]. Preventing perioperative hypothermia is therefore critical.

It is recommended that physicians assess the risk factors associated with perioperative hypothermia to reduce hypothermia-related complications [3, 11]. After assessing these risk factors, physicians should employ interventions that are appropriately designed for the specific patient population and type of operation $[1-3,10]$. The use of cold intravenous fluids is one of the most potentially modifiable risk factors $[5,12]$. The National Institute for Health and Care Excellence (NICE) published clinical guidelines in 2008 that support the use of intravenous fluid warmers to prevent perioperative hypothermia [13]. Using such a device to warm

C C The Author(s). 2021 Open Access This article is licensed under a Creative Commons Attribution 4.0 International License, which permits use, sharing, adaptation, distribution and reproduction in any medium or format, as long as you give appropriate credit to the original author(s) and the source, provide a link to the Creative Commons licence, and indicate if changes were made. The images or other third party material in this article are included in the article's Creative Commons licence, unless indicated otherwise in a credit line to the material. If material is not included in the article's Creative Commons licence and your intended use is not permitted by statutory regulation or exceeds the permitted use, you will need to obtain permission directly from the copyright holder. To view a copy of this licence, visit http://creativecommons.org/licenses/by/4.0/ The Creative Commons Public Domain Dedication waiver (http://creativecommons.org/publicdomain/zero/1.0/) applies to the data made available in this article, unless otherwise stated in a credit line to the data. 
intravenous fluids before administering it to the patient has been shown to prevent inadvertent hypothermia [4, 5, 12]. However, there are various conditions during fluid administration that must be considered, such as the fluid warmer type, flow rate, fluid temperature, and the IV line length, because the conditions may affect the actual temperature of the administered fluid. Therefore, it is critical to investigate the performance of a fluid warmer in different circumstances.

Numerous commercially available fluid warmers, such as Ranger, ThermoSens, Mega Acer Kit, FT800, and Hotline HL-90, have been investigated under different flow rates and room temperatures [12, 14-16]. However, previous studies mainly focused on changing the flow rate $[12,14,15]$. To determine the clinical effectiveness, various clinical factors such as the initial fluid temperature and the use of extension lines should also be considered.

The purpose of this study was to evaluate the fluid heating capabilities of Barkey S-line and Hotline HL-90 according to different flow rates, fluid temperatures, and the presence of an extension line.

\section{Methods}

This study was performed in the designated spot next to the nursing station in the post-anesthesia care unit (PACU). The PACU room temperature was maintained at $23{ }^{\circ} \mathrm{C}$, and the humidity level was maintained at approximately $20 \%$. Normal saline fluid $(0.9 \%$ sodium chloride solution, CJ, Seoul, Republic of Korea) was used for all the experiments in this study. The fluid temperature was measured using a two-channel thermometer (ThermaQ; ThermoWorks, London, UK). For Barkey S-line (Barkey GmbH \& Co. KG, Leopoldshöhe, Germany), the operating temperature was maintained at $39.5{ }^{\circ} \mathrm{C}$ throughout the experiments. A standard infusion set was inserted in the 1.5-m heating profile of S-line according to the manufacturer instructions. For Hotline HL-90 (Smiths Medical, Minneapolis, MN), the operating temperature was set to $40{ }^{\circ} \mathrm{C}$. The REF L-70 disposable tubing system (length $2.4 \mathrm{~m}$, volume load $20 \mathrm{ml}$; Level 1 Technologies Inc., MA, USA) was installed according to the manufacturer instructions.

We evaluated the efficacy of the two fluid warmers under several conditions. Three different conditions were set for the initial fluid temperature: room temperature $\left(22-23{ }^{\circ} \mathrm{C}\right)$, cold $\left(9-10{ }^{\circ} \mathrm{C}\right)$, and warm $(46-$ $47{ }^{\circ} \mathrm{C}$ ). The normal saline solutions were respectively maintained for $12 \mathrm{~h}$ in the operating room, in a refrigerator, and in a heating cabinet for each of the three different conditions. Two distinct flow rates were tested in this study: $100 \mathrm{ml} / \mathrm{hr}$ and $250 \mathrm{ml} / \mathrm{hr}$. The roller clamp was fully open, and the flow rate was adjusted using a micro-flow regulator (I.V. Flow Control Line, Insung
Medical Co., Seoul, Republic of Korea) attached to the infusion set at a flow rate of 100 or $250 \mathrm{ml} / \mathrm{hr}$. The regulator tolerance ranged from $-10-20 \%$ according to the manufacturer instructions. The height of the infusion bag was the same in all experiments $(1.8 \mathrm{~m})$. One unit of a non-insulated extension set (DEHP-free Extension Plus, SBD Medical, Republic of Korea), which was $90 \mathrm{~cm}$ in length, was connected to the fluid warmer outlet. The fluid temperature was measured at two points, first at the fluid warmer outlet $\left(\mathrm{T}_{\text {Prox }}\right)$ and then at the end of the non-insulated extension line $\left(\mathrm{T}_{\text {Distal }}\right)$. After starting each trial, the temperatures at the two positions $\left(T_{\text {Prox }}\right.$ and $\left.\mathrm{T}_{\text {Distal }}\right)$ were recorded every minute until the end of the trial (Fig. 1).

$\mathrm{T}_{\text {Prox }}$ and $\mathrm{T}_{\text {Distal }}$ were carefully evaluated for the presence of a plateau in each trial. The plateau in each trial was defined as the time point at which the measured temperatures were the most stable without a noted fluctuation for $3 \mathrm{~min}$. In each trial, only the $\mathrm{T}_{\text {Prox }}$ and $\mathrm{T}_{\text {Distal }}$ values from the middle time point of the plateau were used for the subsequent statistical analysis. Five trials were performed for an individual experimental condition to obtain five data points for $\mathrm{T}_{\text {Prox }}$ and $\mathrm{T}_{\text {Distal }}$, respectively.

Statistical analysis was performed using SPSS v.20.0 for Windows (IBM SPSS, Inc., Armonk, NY) and R software version 3.4.4 (R Foundation for Statistical Computing, Austria). A data chart was produced using Microsoft Excel 2007. All fluid temperatures were reported as a median (interquartile [IQR] range). The Wilcoxon signed-rank test was used to test for a statistical difference between $\mathrm{T}_{\text {Prox }}$ and $\mathrm{T}_{\text {Distal }}$ values. The Hodges-Lehmann estimator was utilized to create the $95 \%$ confidence interval for the median difference between $\mathrm{T}_{\text {Prox }}$ and $\mathrm{T}_{\text {Distal. }}$. The Mann-Whitney $\mathrm{U}$ test was employed to compare $\mathrm{T}_{\text {Prox }}$ or $\mathrm{T}_{\text {Distal }}$ values under different flow rates using the same fluid warmer or between Hotline and S-line at the same flow rate. The bootstrap method was applied to form the 95\% confidence interval for the analyses performed using the Mann-Whitney U test. Statistical significance was defined as a $p$-value $<0.05$.

\section{Results}

\section{Room-temperature fluid}

The room-temperature fluid was maintained at 21$23{ }^{\circ} \mathrm{C} . \mathrm{T}_{\text {Prox }}$ was higher in Hotline $\left(38.7[38.7-38.8]^{\circ} \mathrm{C}\right)$ than in S-line $\left(28.2[27.6-28.4]^{\circ} \mathrm{C}\right)$ based on the median difference of $10.5{ }^{\circ} \mathrm{C}(95 \% \mathrm{CI} 9.6-12.3)$ at the flow rate of $250 \mathrm{ml} / \mathrm{hr}$. At the flow rate of $100 \mathrm{ml} / \mathrm{hr}$, the $\mathrm{T}_{\text {Prox }}$ value was higher in Hotline $\left(40.3[40.1-40.4]^{\circ} \mathrm{C}\right)$ than $\mathrm{S}$ line $\left(38.7[38.6-38.7]^{\circ} \mathrm{C}\right)$ according to the median difference of $1.6{ }^{\circ} \mathrm{C}$ (95\% CI 1.4-2.1. $\mathrm{T}_{\text {Distal }}$ measured higher in Hotline $\left(37.6[37.6-37.9]^{\circ} \mathrm{C}\right)$ than in S-line $(27.8$ 

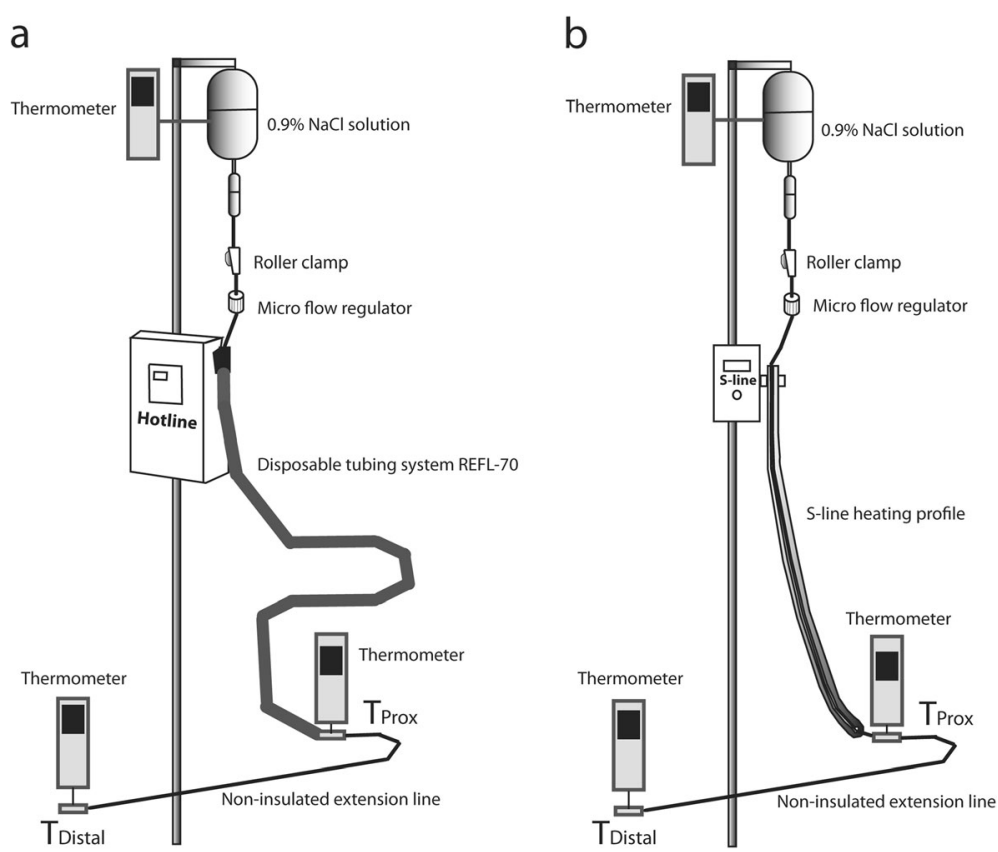

Fig. 1 The figure shows an overview of the experimental setup. $0.9 \% \mathrm{NaCl}$ solution is warmed as it travels down the fluid warmer. After fluid exits the warmer, it goes further down through the non-insulated extension line. The temperatures at the outlet of the warmer ( $T_{\text {prox }}$ ) and the outlet of the extension line ( $T_{\text {Distal }}$ ) were measured using thermometers. $a$ and $b$ in the left and right show the setups for Hotline and S-line, respectively
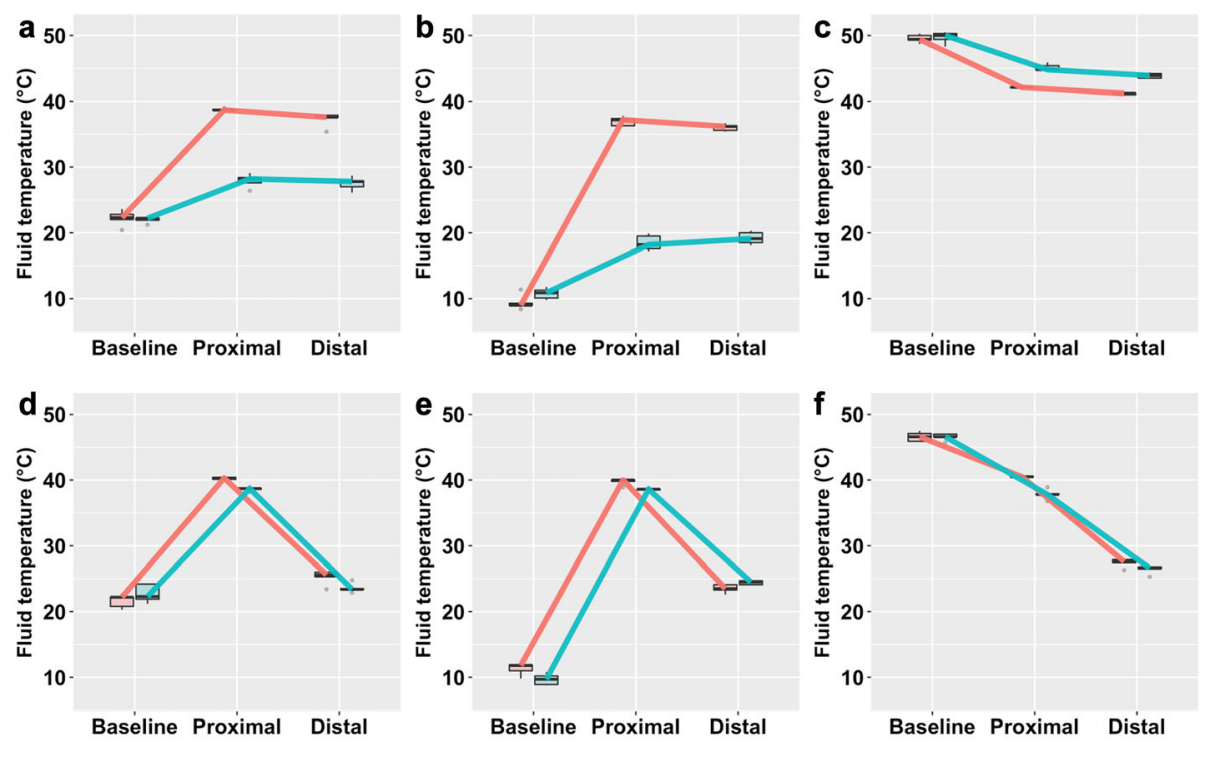

‡Hotline官S-line

Fig. 2 The figure illustrates the measured fluid temperatures using boxplots and line graphs. The red line and blue line connect the data from Hotline and S-line respectively. Boxes indicate the interquartile range, the bold horizontal lines in the box are the median values, and the whiskers are the range. Outliers are displayed as dots. a room-temperature fluid at $250 \mathrm{ml} / \mathrm{hr}$, b cold fluid at $250 \mathrm{ml} / \mathrm{hr}, \mathbf{c}$ warm fluid at $250 \mathrm{ml} / \mathrm{hr}$, d room-temperature fluid at $100 \mathrm{ml} / \mathrm{hr}$, e cold fluid at $100 \mathrm{ml} / \mathrm{hr}$, f warm fluid at $100 \mathrm{ml} / \mathrm{hr}$ 
[27.0-27.9 ${ }^{\circ} \mathrm{C}$ ) based on the median difference of $9.8^{\circ} \mathrm{C}$ (95\% CI 7.6-11.5) at the flow rate of $250 \mathrm{ml} / \mathrm{hr}$. However, the $\mathrm{T}_{\text {Distal }}$ values were not significantly different between Hotline $\left(25.6[25.3-26.0]^{\circ} \mathrm{C}\right)$ and S-line (23.4 [23.4-23.5 ${ }^{\circ} \mathrm{C}$ ) at $100 \mathrm{ml} / \mathrm{hr}$ (Fig. 2).

$\mathrm{T}_{\text {Prox }}$ in Hotline was slightly higher at $100 \mathrm{ml} / \mathrm{hr}$ than at $250 \mathrm{ml} / \mathrm{hr}$ based on the median difference of $1.6^{\circ} \mathrm{C}$ (95\% CI 1.3-1.9). However, $\mathrm{T}_{\text {Prox }}$ in $\mathrm{S}$-line was much higher at $100 \mathrm{ml} / \mathrm{hr}$ than at $250 \mathrm{ml} / \mathrm{hr}$ based on the median difference of $10.5{ }^{\circ} \mathrm{C}$ (95\% CI 9.6-12.3).

Furthermore, $\mathrm{T}_{\text {Distal }}$ in Hotline was higher at $250 \mathrm{ml} /$ $\mathrm{hr}$ than at $100 \mathrm{ml} / \mathrm{hr}$ by $12.0{ }^{\circ} \mathrm{C}(95 \%$ CI $9.8-14.2)$. $\mathrm{T}_{\text {Dis- }}$ tal in S-line was higher at $250 \mathrm{ml} / \mathrm{hr}$ than at $100 \mathrm{ml} / \mathrm{hr}$ by $4.4{ }^{\circ} \mathrm{C}(95 \% \mathrm{CI} 2.6-5.3)$. The $\mathrm{T}_{\text {Distal }}$ values were lower at $100 \mathrm{ml} / \mathrm{hr}$ than at $250 \mathrm{ml} / \mathrm{hr}$. In addition, $\mathrm{T}_{\text {Prox }}$ was higher than $\mathrm{T}_{\text {Distal }}$ in both devices regardless of the flow rate. However, the differences were more substantial at $100 \mathrm{ml} / \mathrm{hr}$. At a flow rate of $250 \mathrm{ml} / \mathrm{hr}$, the median differences between $\mathrm{T}_{\text {Prox }}$ and $\mathrm{T}_{\text {Distal were } 1.1{ }^{\circ} \mathrm{C}(95 \% \mathrm{CI}}$ $0.9-2.2)$ in Hotline and $0.4{ }^{\circ} \mathrm{C}(95 \%$ CI $0.3-0.6)$ in $\mathrm{S}$ line. At $100 \mathrm{ml} / \mathrm{hr}$, the median differences were $14.7{ }^{\circ} \mathrm{C}$ (95\% CI 14.3-16.7) in Hotline and $15.1{ }^{\circ} \mathrm{C}$ (95\% CI 13.9-16.0) in S-line.

\section{Cold fluid}

The initial temperature of the starting solution was maintained at $9-11{ }^{\circ} \mathrm{C}$ in this group. $\mathrm{T}_{\text {Prox }}$ was higher in Hotline $\left(37.2[36.3-37.4]^{\circ} \mathrm{C}\right)$ than in S-line $(18.2$ [17.6$\left.19.5]^{\circ} \mathrm{C}\right)$ by the median difference of $19.0{ }^{\circ} \mathrm{C}(95 \% \mathrm{CI}$ $16.7-20.2)$ at $250 \mathrm{ml} / \mathrm{hr}$. However, the difference between Hotline $\left(40.0[39.8-40.0]^{\circ} \mathrm{C}\right)$ and S-line (38.6 [38.5-38.6 $\left.]^{\circ} \mathrm{C}\right)$ was $1.4{ }^{\circ} \mathrm{C}(95 \% \mathrm{CI} 0.3-4.3)$ at $100 \mathrm{ml} / \mathrm{hr}$. $\mathrm{T}_{\text {Distal }}$ at $250 \mathrm{ml} / \mathrm{hr}$ was also higher in Hotline $(36.2$ $\left.[35.6-36.3]^{\circ} \mathrm{C}\right)$ than in S-line $\left(19.1[18.5-20.0]^{\circ} \mathrm{C}\right)$ based on the median difference of $17.1{ }^{\circ} \mathrm{C}$ (95\% CI 15.4-18.2). However, the $\mathrm{T}_{\text {Distal }}$ values from Hotline (23.5 [23.3$24.1]^{\circ} \mathrm{C}$ ) and S-line $\left(24.5[24.1-24.7]^{\circ} \mathrm{C}\right)$ were not statistically different at $100 \mathrm{ml} / \mathrm{hr}$ (Fig. 2).

$\mathrm{T}_{\text {Prox }}$ measured in Hotline was slightly higher at $100 \mathrm{ml} / \mathrm{hr}$ than at $250 \mathrm{ml} / \mathrm{hr}$ by $2.8{ }^{\circ} \mathrm{C}(95 \%$ CI $1.7-3.8)$. In $\mathrm{S}$-line, the $\mathrm{T}_{\text {Prox }}$ value was significantly higher at $100 \mathrm{ml} / \mathrm{hr}$ than at $250 \mathrm{ml} / \mathrm{hr}$ by $20.4{ }^{\circ} \mathrm{C}(95 \%$ CI $17.5-$ 21.4). For $T_{\text {Distal }}$ in Hotline, the temperature at $250 \mathrm{ml} /$ hr was higher than at $100 \mathrm{ml} / \mathrm{hr}$, and the median difference was $12.7{ }^{\circ} \mathrm{C}(95 \% \mathrm{CI} 11.4-13.6)$. In contrast, $\mathrm{T}_{\text {Distal }}$ at $100 \mathrm{ml} / \mathrm{hr}$ was higher than at $250 \mathrm{ml} / \mathrm{hr}$ in S-line, and the median difference was $5.4{ }^{\circ} \mathrm{C}(95 \%$ CI $4.0-6.4)$. In both devices, the $T_{\text {Distal }}$ values at $100 \mathrm{ml} / \mathrm{hr}$ were similar to the ambient temperature. The $\mathrm{T}_{\text {Prox }}$ was higher than $\mathrm{T}_{\text {Distal }}$ in both devices regardless of the flow rate. The only exception was observed in S-line at $250 \mathrm{ml} / \mathrm{hr}$; $\mathrm{T}_{\text {Prox }}$ is $18.2^{\circ} \mathrm{C}$ and $\mathrm{T}_{\text {Distal }}$ is $19.1{ }^{\circ} \mathrm{C}$. The difference between $\mathrm{T}_{\text {Prox }}$ and $\mathrm{T}_{\text {Distal }}$ was greater at $100 \mathrm{ml} / \mathrm{hr}$ than at $250 \mathrm{ml} / \mathrm{hr}$. At $250 \mathrm{ml} / \mathrm{hr}$, the median differences

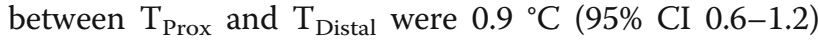
in Hotline and $0.7{ }^{\circ} \mathrm{C}(95 \% \mathrm{CI} 0.5-0.9)$ in S-line. At $100 \mathrm{ml} / \mathrm{hr}$, the median differences were $16.3{ }^{\circ} \mathrm{C}(95 \% \mathrm{CI}$ 15.8-16.6) in Hotline and $13.9{ }^{\circ} \mathrm{C}$ (95\% CI 11.2-14.6) in S-line. At $100 \mathrm{ml} / \mathrm{hr}$, the extension line reversed most of the warming and substantially cooled the fluid as it traveled from $\mathrm{T}_{\text {Prox }}$ to $\mathrm{T}_{\text {Distal. }}$.

\section{Warm fluid}

The initial fluid temperature was maintained at $46-49{ }^{\circ} \mathrm{C}$ in the warm temperature group. In this temperature group, the temperature of the initial fluid was higher than the operating temperatures of the fluid warmers themselves. The $\mathrm{T}_{\text {Prox }}$ value at $250 \mathrm{ml} / \mathrm{hr}$ in S-line (44.8 [44.7$\left.45.4]^{\circ} \mathrm{C}\right)$ was higher than in Hotline $\left(42.1[42.1-42.1]^{\circ} \mathrm{C}\right)$ according to the median difference of $2.7^{\circ} \mathrm{C}$ (95\% CI 2.43.8). At $100 \mathrm{ml} / \mathrm{hr}$, the $\mathrm{T}_{\text {Prox }}$ value was higher in Hotline $\left(40.5[40.5-40.5]^{\circ} \mathrm{C}\right)$ than S-line $\left(37.8[37.8-37.9]^{\circ} \mathrm{C}\right)$ according to the median difference of $2.7{ }^{\circ} \mathrm{C}(95 \% \mathrm{CI} 1.6-$ 3.7). $\mathrm{T}_{\text {Distal }}$ in $\mathrm{S}$-line $\left(43.9[43.5-44.2]^{\circ} \mathrm{C}\right)$ at $250 \mathrm{ml} / \mathrm{hr}$ was higher than in Hotline $\left(41.2[41.0-41.2]^{\circ} \mathrm{C}\right)$ according to the median difference of $2.7{ }^{\circ} \mathrm{C}$ (95\% CI 2.2-3.2). At $100 \mathrm{ml} / \mathrm{hr}$, no statistical difference existed between the

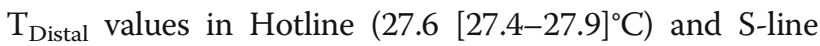
(26.6 [26.5-26.8 $\left.]^{\circ} \mathrm{C}\right)$ (Fig. 2).

In Hotline, the $\mathrm{T}_{\text {Prox }}$ value was higher at $250 \mathrm{ml} / \mathrm{hr}$ than at $100 \mathrm{ml} / \mathrm{hr}$, and the median difference was $1.6{ }^{\circ} \mathrm{C}$ (95\% CI 1.5-1.7). For the $\mathrm{T}_{\text {Distal value, the temperature }}$ measured at $250 \mathrm{ml} / \mathrm{hr}$ was again higher, and the median difference was $13.6{ }^{\circ} \mathrm{C}$ (95\% CI 13.1-14.9). Similarly, the $\mathrm{T}_{\text {Prox }}$ value in S-line was higher at $250 \mathrm{ml} / \mathrm{hr}$ than at $100 \mathrm{ml} / \mathrm{hr}$; the median difference was $7.0{ }^{\circ} \mathrm{C}(95 \% \mathrm{CI}$ 5.9-8.1). For the $\mathrm{T}_{\text {Distal }}$ value, the measurement at $250 \mathrm{ml} / \mathrm{hr}$ was higher than at $100 \mathrm{ml} / \mathrm{hr}$ based on the median difference of $17.3{ }^{\circ} \mathrm{C}$ (95\% CI 16.7-18.6). $\mathrm{T}_{\text {Prox }}$ was higher than $\mathrm{T}_{\text {Distal }}$ at the two flow rates in both Hotline and S-line. A flow rate of $100 \mathrm{ml} / \mathrm{hr}$ produced larger differences between $\mathrm{T}_{\text {Prox }}$ and $\mathrm{T}_{\text {Distal }}$. At $250 \mathrm{ml} / \mathrm{hr}$, the median differences between $\mathrm{T}_{\text {Prox }}$ and $\mathrm{T}_{\text {Distal }}$ were $1.0{ }^{\circ} \mathrm{C}$ (95\% CI 0.9-1.1) in Hotline and $1.2{ }^{\circ} \mathrm{C}$ (95\% CI 0.8-1.5) in S-line. At $100 \mathrm{ml} / \mathrm{hr}$, the median differences were $12.9{ }^{\circ} \mathrm{C}(95 \% \mathrm{CI} 12.5-14.2)$ in Hotline and $11.3{ }^{\circ} \mathrm{C}(95 \%$ CI 11.1-12.1) in S-line. The slower flow rate correlated with a more substantial difference in the median values.

\section{Discussion}

This study showed that Hotline was superior to S-line for warming fluids when using room-temperature or cold saline at a high flow rate. However, at a low flow rate, the fluid temperature significantly decreased in both devices after passing through an extension line.

The difference in heating capacity between the two devices was likely due to the differences in their respective heating mechanisms, i.e., a coaxial circulating water bath 
(Hotline) versus a dry heating profile (S-line). The dryheating system is expected to incur greater heat losses on account of the exposed portion of the extension line in ambient temperature. Thus, the Hotline coaxial warming system is apparently more effective than S-line in preventing hypothermia during rapid fluid administration. When administrating fluid rapidly, pre-warming fluid appears to be effective in maintaining fluid temperature warm especially in S-line. However, it would be important to check the warming temperature beforehand to avoid getting too hot fluid.

At $100 \mathrm{ml} / \mathrm{hr}$, changing the initial temperature affected the $\mathrm{T}_{\text {Prox }}$ less in both Hotline and S-line. The slow flow rate would have provided sufficient time for both fluid warmers to affect the fluid temperatures. However, $\mathrm{T}_{\text {dis- }}$ tal of the warm fluid seem to be slightly higher than those of the room-temperature or cold fluids at $100 \mathrm{ml} /$ $\mathrm{hr}$ in both Hotline and S-line. This suggests that using pre-warmed fluid may have some role in maintaining fluid temperature even at the low flow rate when the extension line is used. Warm fluid could have influenced $\mathrm{T}_{\text {Distal }}$ through heating up the tube in which the fluid traveled down, however, the exact mechanism behind this finding remains to be further investigated.

There are several studies evaluating the performance of fluid warmers in literature $[4,12,15,16]$. The previous studies produced detailed analyses on effect of changing one or two variables on the final fluid temperature among different fluid warmers. For example, the studies were descriptive of the effect of changing the flow rate or the initial fluid temperature. The current study has a strength that it analyzed how extension line, flow rate and initial fluid temperature interact to influence the final fluid temperature and presented comprehensive and clinically relevant performance profiles of Hotline and S-line.

It is clinically important to determine whether warmed fluids can be delivered to the patient without heat loss as they pass through a non-insulated extension line. Interestingly, in this study, a statistically significant change in fluid temperature was observed after the extension line in every experimental condition regardless of the fluid warmer type, initial fluid temperature, or flow rate. The change in fluid temperature was more pronounced at the low flow rate than at the high one. The fluid lost a significant amount of heat as it traveled an additional $90 \mathrm{~cm}$ at a rate of $100 \mathrm{ml} / \mathrm{hr}$. This finding warrants the utilization of additional measures for hypothermia prevention when using an extension at the low flow rate, especially when administering fluids to patients with a high risk of developing hypothermia such as neonatal and older patients [17]. Furthermore, it is essential to minimize heat loss as the fluid travels down the extension line, which can be achieved by an extension line innovation or by applying supplemental measures against hypothermia.

Several limitations of this study should be noted. In an actual clinical setting, the fluid administration rate, initial fluid temperature, and extension line length may differ from the conditions used in this study. For example, during rapid fluid resuscitation, the infusion rate can be as high as 60 to $80 \mathrm{~mL} / \mathrm{kg}$ per hour [18]. Also, in this study, the fluid temperature in the warm temperature group was greater than $45^{\circ} \mathrm{C}$, which can be problematic because the proteins in red blood cells can degenerate at a temperature higher than $45^{\circ} \mathrm{C}$ [19]. Moreover, precautionary measures should be taken against preparing fluids that are excessively hot for clinical practice. Finally, extension lines longer than $90 \mathrm{~cm}$ can be employed in certain clinical scenarios. Longer extension lines could affect the fluid temperature more markedly than the line length employed in this study.

\section{Conclusions}

In summary, Hotline outperformed S-line for warming fluids at a high flow rate with cold or room-temperature fluids. Administering warm fluid in S-line prevented a decrease in the fluid temperature at a high flow rate. Finally, using an extension line can reduce the final fluid temperature delivered to the patient at a low flow rate in both devices.

\section{Abbreviations \\ $T_{\text {Prox: }}$ Temperature at the fluid warmer point; $T_{\text {Distal }}$ : Temperature at the extension line point; PACU: Post-anesthesia care unit \\ Acknowledgements \\ Not applicable.}

Authors' contributions

HK and TKK collected and analyzed the study data. SY and J-TK designed the study and interpreted the study data. HK and TKK were the major contributors in writing the manuscript. All authors read and approved the final manuscript.

\section{Funding}

Support was provided solely from departmental resources of the Department of Anesthesiology and Pain Medicine, Seoul National University Hospital.

Availability of data and materials

The datasets used and/or analysed during the current study are available from the corresponding author on reasonable request.

Ethics approval and consent to participate

Not applicable.

Consent for publication

Not applicable.

Competing interests

The authors declare that they have no competing interests.

\section{Author details}

${ }^{1}$ College of Medicine, Seoul National University, Seoul, Republic of Korea. ${ }^{2}$ Department of Anesthesiology and Pain Medicine, SMG-SNU Boramae Medical Center, Seoul, Republic of Korea. ${ }^{3}$ Department of Anesthesiology 
and Pain Medicine, Seoul National University Hospital, 101 Daehak-ro, Jongno-gu, 03080 Seoul, Republic of Korea.

Received: 29 August 2020 Accepted: 22 December 2020

Published online: 04 January 2021

\section{References}

1. Diaz M, Becker DE. Thermoregulation: physiological and clinical considerations during sedation and general anesthesia. Anesth Prog. 2010; 57(1):25-32. quiz $33-24$

2. Matika R, Ibrahim M, Patwardhan A. The importance of body temperature: An anesthesiologist's perspective. Temperature (Austin). 2017;4(1):9-12.

3. Sessler DI. Temperature monitoring and perioperative thermoregulation. Anesthesiology. 2008;109(2):318-38.

4. Tansey EA, Johnson CD. Recent advances in thermoregulation. Adv Physiol Educ. 2015;39(3):139-48.

5. Wax DB, Tyson W, Smith N. Avoidance of Inadvertent Hypothermia With a Fluid-Warming/Infusion System. J Cardiothorac Vasc Anesth. 2018;32(5):e4-5.

6. Moola S, Lockwood C. Effectiveness of strategies for the management and/ or prevention of hypothermia within the adult perioperative environment. Int J Evid Based Healthc. 2011;9(4):337-45.

7. Billeter AT, Hohmann SF, Druen D, Cannon R, Polk HC Jr. Unintentional perioperative hypothermia is associated with severe complications and high mortality in elective operations. Surgery. 2014;156(5):1245-52.

8. Flores-Maldonado A, Medina-Escobedo CE, Rios-Rodriguez HM, FernandezDominguez R. Mild perioperative hypothermia and the risk of wound infection. Arch Med Res. 2001;32(3):227-31.

9. Mahoney $\mathrm{CB}$, Odom J. Maintaining intraoperative normothermia: a metaanalysis of outcomes with costs. AANA J. 1999;67(2):155-63.

10. Tsuei BJ, Kearney PA. Hypothermia in the trauma patient. Injury. 2004:35(1):7-15.

11. Moran DS, Mendal L. Core temperature measurement: methods and current insights. Sports Med. 2002;32(14):879-85.

12. Zoremba N, Bruells $C$, Rossaint $R$, Breuer T. Heating capabilities of small fluid warming systems. BMC Anesthesiol. 2018;18(1):98.

13. National Institute for Health and Care Excellence. (2008) Hypothermia: prevention and management in adults having surgery. https://www.nice. org.uk/guidance/cg65. Accessed 23 March 2020

14. Xu X, Lian C, Liu Y, Ding H, Lu Y, ShangGuan W. Warming efficacy of Ranger and FT2800 fluid warmer under different room temperatures and flow rates. J Clin Monit Comput. 2020;34(5):1105-10.

15. Thongsukh V, Kositratana C, Jandonpai A. Effect of Fluid Flow Rate on Efficacy of Fluid Warmer: An In Vitro Experimental Study. Anesthesiol Res Pract. 2018;2018:4

16. Kim DJ, Kim SH, So KY, An TH. Mega Acer Kit(R) is more effective for warming the intravenous fluid than Ranger and ThermoSens(R) at $440 \mathrm{ml} / \mathrm{h}$ of infusion rate: an experimental performance study. Korean J Anesthesiol. 2017;70(4):456-61

17. Macario A, Dexter $F$. What are the most important risk factors for a patient's developing intraoperative hypothermia? Anesth Analg. 2002;94(1):215-20. table of contents.

18. Santry HP, Alam HB. Fluid resuscitation: past, present, and the future. Shock. 2010;33(3):229-41.

19. Gershfeld NL, Murayama M. Thermal instability of red blood cell membrane bilayers: temperature dependence of hemolysis. J Membr Biol. 1988;101(1) 67-72.

\section{Publisher's Note}

Springer Nature remains neutral with regard to jurisdictional claims in published maps and institutional affiliations.

Ready to submit your research? Choose BMC and benefit from:

- fast, convenient online submission

- thorough peer review by experienced researchers in your field

- rapid publication on acceptance

- support for research data, including large and complex data types

- gold Open Access which fosters wider collaboration and increased citations

- maximum visibility for your research: over $100 \mathrm{M}$ website views per year

At $\mathrm{BMC}$, research is always in progress.

Learn more biomedcentral.com/submissions 